\title{
Changing places, changing tracks: Inter-school mobility among Czech secondary students
}

Dominik Dvořák, Petr Meyer, Silvie R. Kučerová, Jan Vyhnálek, Ondřej Šmíd

Abstract: Most of the literature on student between-track mobility or school choice examines decision making in comprehensive systems or in tracked general education schools. In this article we present data on inter-school mobility (transfers) of upper secondary students in a differentiated educational system with academic, professional and vocational tiers and with a complex scheme of programmes and qualifications. This study is based on administrative microdata from the Czech school register merged with databases containing geographical information. We performed an explorative analysis of 4,533 events of school change with focus on the spatial aspects of VET student transfers. The preliminary results confirm the usefulness of this approach in studying the role school distance plays in programme and school choice.

Key words: school choice, tracking, inter-school mobility, transitions, spatial data, vocational education

\section{Introduction}

In recent years, there has been renewed interest within social science in education-related mobility, often understood simultaneously in a social and spatial/material sense and inspired by Latourian actor-network theories (Landri \& Neumann, 2014). Inter-school mobility can be understood in both the geographical and status-oriented sense. Research into the former often relates to periodic travel - commuting to school (daily, or weekly for some 
schools). The latter is often concerned with various types of more or less irreversible change such as inter-generational upward educational mobility, but also segments of passages within the individual's educational path. These could be either vertical school transitions (progressing to a higher level of education) or horizontal transfers (inter-school mobility - switching schools at non-normative points). Inter-generational upward mobility is the consequence of a sequence of successful vertical school transitions in individual educational trajectories, while inter-school mobility might be a reaction to a failed vertical transition.

Horizontal student mobility (transitions at non-normative points, school switching/changing) is defined as "a child joining or leaving a school at a point other than the normal age at which children start or finish their education at that school, whether or not this involves a move of home" (Dobson, 2008, p. 301). We will use the term "transfer" to describe mobility that differs from the normal transition (progression) to a higher level of education and to distinguish from an early leaving of education.

Transfers or changing school might be considered fairly unproblematic and neutral, for example when it is the result of ordinary spatial mobility in the population. It may even be welcome proof that the education system enables students or parents to make repeated school choices (Chubb \& Moe, 1990) and thus correct a prior choice of school or programme. On the other hand, some cases of horizontal mobility may be cause for concern if they are the result of negative events in the individual's life (school failure - often connected with other problems the student or family have - Rumberger, 2003), in the teacher-student or teacher-student relationship, or may even be a manifestation of system-wide failure (e.g. schools underserving particular groups of students).

Previous studies of inter-school mobility in the Czech system (Dvořák, Starý, \& Vyhnálek, 2016; Dvořák \& Vyhnálek, 2019; Hlad’o \& Šlapalová, 2019) have used qualitative techniques to explore the perspectives of different actors involved in transfers (students and their classmates, parents, teachers). Wider perspectives, rooted in larger scales of statistical, quantitative data and combining multidisciplinary views are rare even in the international literature (Koinzer, Nikolai \& Waldow, 2017). Our focus here is to share insights into the structural factors that constrain or enable individuals making decisions about school choice and changing school. Dvoŕák \& Vyhnálek (2019) have highlighted the potential offered by data compiled by the ministry of education and other governmental agencies for researchers 
studying student choices in the Czech upper secondary system, which is a very complex educational system with different tracks and hundreds of programmes. Their study, however, discussed status mobility on the level of three main tiers only.

The primary aim of our paper is methodological: to explore the potential for using student register data to analyse spatial and social trajectories of students choosing and switching school. We present a process for merging three Czech nationalwide databases, which would make it possible to study inter-school mobility at the macro-regional level to identify general trends in choosing and changing school trajectories. The second aim is to refine the analysis of student mobility in Czechia by looking at the different tracks and programmes within the vocational education and training tier (VET), and by exploring the role of spatial factors in school mobility. We want to answer these research questions: How does the typical home to school distance differ for mobile students in different tiers of upper secondary education? What is the ratio of downward and upward changes in tier and track? How often do Czech VET students stay in the same field of study when changing school? How does the decision to change field of study in VET relate to a change in home-school distance?

\section{Context: Czech Upper Secondary Education}

The focus of our study is the Czech upper secondary school system. It is a differentiated system with a very high share of students in the techni$\mathrm{cal} /$ professional and vocational study tiers (see Table 1). One problem with the research literature on horizontal mobility is the variety of definitions of tracks, and hence the conceptualisation of transfers are very different across the various studies (Blossfeld, 2018). That is why we provide an account of Czech post-compulsory education and its tiers, tracks, and programmes.

Czech students are sorted into two tiers already after 5th grade: approximately $10 \%$ of students enter a selective 8-year grammar school (viceleté gymnázium), while the majority of students stay at a a comprehensive school (základní škola, literally "basic school”). Students who complete their lower secondary education in the comprehensive tier can be admitted to any upper secondary tier: academic 4-year grammar tier (gymnázium), techni$\mathrm{cal} /$ professional tier or VET tier. To transit to the academic or professional tier, comprehensive school graduates have to sit a national admission test; however, no minimal required test score/level of knowledge has been set. 
Table 1 Main tracks in Czech upper secondary education

\begin{tabular}{|c|c|c|c|c|c|}
\hline $\begin{array}{l}\text { Czech } \\
\text { code }\end{array}$ & $\begin{array}{l}\text { ISCED } \\
97\end{array}$ & $\begin{array}{c}\text { ISCED } \\
2011\end{array}$ & $\begin{array}{c}\text { Czech name(s), } \\
\text { abbreviations and } \\
\text { translation }\end{array}$ & Track characteristics & $\begin{array}{c}\begin{array}{c}\text { Share of } \\
\text { students } \\
(\%)\end{array} \\
\end{array}$ \\
\hline $\mathrm{K}$ & \multirow{3}{*}{$3 \mathrm{~A}$} & 344 & $\begin{array}{l}\text { Gymnázium (G) } \\
\text { Grammar school }\end{array}$ & $\begin{array}{l}\text { academic tier ( } 4 \text { years) } \\
\text { secondary education leading } \\
\text { to a maturita certificate and } \\
\text { preparing students for studies } \\
\text { at any higher education } \\
\text { institution } \\
\end{array}$ & 22.5 \\
\hline M & & $\begin{array}{l}354 \\
344\end{array}$ & $\begin{array}{l}\text { Střední odborná } \\
\text { škola (SOŠ) } \\
\text { Lyceum } \\
\text { Secondary } \\
\text { Technical School }\end{array}$ & $\begin{array}{l}\text { professional tier (4 years) } \\
\text { non-academic professionally } \\
\text { oriented technical } \\
\text { programmes leading to the } \\
\text { maturita certificate }\end{array}$ & 37.5 \\
\hline $\mathrm{L}(0)$ & & 354 & $\begin{array}{l}\text { Střední odborné } \\
\text { učiliště s maturitou } \\
\text { (SOU) } \\
\text { Vocational School }\end{array}$ & $\begin{array}{l}\text { VET tier (4 years) } \\
\text { maturita certificate (a small } \\
\text { number of programmes } \\
\text { lead to an apprenticeship } \\
\text { certificate) }\end{array}$ & 6.0 \\
\hline $\mathrm{H}$ & \multirow[b]{2}{*}{$3 \mathrm{C}$} & 353 & \begin{tabular}{|l} 
Střední odborné \\
učiliště (SOU) \\
Vocational School
\end{tabular} & $\begin{array}{l}\text { VET tier ( } 3 \text { years) } \\
\text { leads to an apprenticeship } \\
\text { certificate and prepares } \\
\text { students for direct entry into } \\
\text { the labour market }\end{array}$ & \multirow[b]{2}{*}{30} \\
\hline $\mathrm{E}$ & & 353 & \begin{tabular}{|l|} 
Střední odborné \\
učiliště (SOU) \\
Vocational School
\end{tabular} & $\begin{array}{l}\text { VET tier (2-3 years) } \\
\text { does not lead to an } \\
\text { apprenticeship certificate; } \\
\text { students are trained to } \\
\text { perform simple auxiliary tasks } \\
\text { in production or services }\end{array}$ & \\
\hline
\end{tabular}

Note: The numbers refer to new entrants from the comprehensive lower secondary schools in the 2017/2018 school year. Students already in 8-year and 6-year academic track not included. Source: Authors, based on (Vojtěch \& Chamoutová, 2018)

Students applying for the VET tier generally do not sit the national test (with one exception). There are no catchment areas or attendance zones so students are free to apply to any upper secondary school in Czechia.

It is important to understand that in the era of state socialism (1948-1989) there was strict between-school differentiation at the upper secondary level. So the typical upper secondary school offered various programmes within a single tier. Nowadays, the school system is more varied and sometimes a school will have two or even three tiers, but many schools still provide just one level of programmes/qualifications - so switching to a different tier often means changing school. Besides the three main tiers, there is a very fragmented system of qualifications within both the professional and VET tiers: students can choose from about three hundred programmes leading to different qualifications (Decree 211/2010 Coll.) that can be grouped into 
about a dozen broad fields of education and training (e.g. mechanical engineering, health care, retail).

After completion of four-year academic and technical/professional programmes, upper secondary school-leaving examination (maturita) is taken and successful candidates are eligible to apply for tertiary education. VET students have to pass a final apprenticeship examination (with a strong practical component) that traditionally facilitates the transition to the labour market but the graduates cannot enter tertiary education unless they have an upper secondary school leaving certificate that requires an additional two or more years of study. Hence the typical three-year vocational programme is often a dead end educational trajectory. The system of vocational education, however, is slightly more complex and provides some alternatives: Beyond the most popular three-year VET programmes (H-track in Czech, which lead to an apprenticeship certificate) there are also four-year VET programmes (L track) that lead to the maturita. The L track is part of the VET tier, but applicants must sit the obligatory national test to be admitted, and successful graduates are entitled to apply for tertiary education. On the other hand, the less demanding VET programmes (2-3 year E track) prepare students for simple auxiliary jobs. We will use the three tier/five track classification scheme described in Table 1. (The art tier differs and is not included here, nor are some lowest-profile VET tracks.)

\section{Literature Review}

While vertical transitions, especially from primary to secondary education, sometimes related to moving from a small/rural school to a large/ urban school have been the subject of research (e.g. Kvalsund, 2000; Walterová, 2011), our paper combines the study of educational and spatial factors in horizontal school transfers. The research literature emphasises social background, ethnic origin and student performance as key factors in change of school leading to change of track (Albrecht et al., 2018; van Praag et al., 2012). In Czechia, several scholars have recently explored the role of socio-economic status and/or academic achievement in the track and career choices of lower secondary students. These studies show that vocational tiers are mainly attended by students with low socio-economic status, even after accounting for their abilities, and that the impact of home background has been increasing (Katrňák, 2004; Straková, 2015; Veselý, 2006). Given the close relationship between changing school and choice of school, we expect decisions about transferring from one school to another to be highly influenced by spatial factors as well. Indeed, results from differ- 
ent European countries show that distance travelled to school is the most important factor in choosing the original school (Meyer \& Kučerová, 2018; Müller et al., 2012; Prieto et al., 2018; Simonová, 2017) both generally and even more so in socio-economically disadvanteged groups (Holloway \& Pimlott-Wilson, 2012).

A systematic review by Vyhnálek (2016) shows that most of the research data on horizontal mobility come from a small number of countries, mainly the United States and the United Kingdom (e.g. Gasper, DeLuca \& Estacion, 2012; Gibbons \& Telhaj, 2011; Mehana \& Reynolds, 2004; Rumberger, 2003; Strand \& Demie, 2006). Patterns of school mobility with and without change of track/programme, however, are influenced by the structure of national education systems and the wider social context. Data from English speaking countries (that tend to have comprehensive school systems) reveal little about the role of tier change (and system permeability) that may be an important feature in some European stratified school systems such as the German, Dutch (Jacob \& Tieben, 2009) or Luxembourgian (Backes \& Hadjar, 2017) systems. The studies of European tracked systems mainly explore the general education phase, that is, primary or lower secondary education (Blossfeld, 2018). It may be possible to draw parallels between decision making in systems with a strong vocational component and parent/student choice of specialty school in the North American context.

But there are other important cultural differences: in some Englishspeaking countries (England being probably the best known example), there is a long tradition in which the most prestigious elite selective schools have been boarding schools attracting students from across the country (Reeves et al., 2017). By contrast, Czech selective/grammar schools are not boarding schools, while the professional and vocational upper secondary schools traditionally provide some boarding (term-time accommodation) to students (in some cases even free of charge). So we can expect that students may choose a fairly specialised school located at a significant distance from home without the need to commute daily. For some adolescents, the choice of a relatively remote secondary school providing accommodation can serve as a significant step in becoming independent and entering adulthood, but without the need to run a household (Eurofound, 2014). Again, some analogies can be found with choosing higher education (as many university students move out of the home and into halls of residence or some other form of temporary housing); in this case the prevailing pattern being the negative distance deterrence effect (Bertrand-Cloodt et al., 2010). 
Another difference is related to perception of school mobility (transfers): "While in the United States mobility has positive connotations related to labour mobility, in the European school systems continuity in the same school has long been the expected practice." (Bereményi \& Carrasco, 2018, p. 36). It is therefore important to study this phenomenon within - and possibly across - different jurisdictions.

In a differentiated system that has some form of between-school tracking/ grouping, changing school might be motivated by an effort to correct a previous choice of tier, track or programme (Hlad’o \& Šlapalová, 2019; Latina, 2017). This may take the form of a waterfall (Danhier \& Martin, 2014) or cascade mechanism (van Praag et al., 2012) where unsuccessful or troublemaking students are "dropped" from academic/grammar schools and change to schools in the professional tier or move from a professional to a vocational education. By comparison, in Israeli secondary education the majority of between-tier mobility is from vocational and professional (engineering and technological tracks) tiers to the academic tier, which is more prestigious (Blank, Shavit \& Yaish, 2015). School transfers with or without programme/ track change might also be the result of factors related less to type of programme and more to the school (or even teacher or classmates). Finally, the principal reason for changing might be related neither to the programme nor the school culture or climate, but to logistical problems relating to the school location and resulting issues with commuting or boarding.

\section{Data and Methods}

In our study, data from three types of nationwide Czech databases have been merged.

1) Czech National Student Register. These administrative data are semiannually reported to the ministry of education by the schools. They are fully anonymised to comply with the ethical and legal requirements of personal data protection. School statistics have been compiled based on these data and are used by administrators and researchers in educational sciences. Nevertheless, the administrative microdata enable the researcher to go deeper than the aggregated averages. The original reported data on each unit - each student - makes new types of analysis possible.

The administrative data on all transfers of Czech upper secondary students from September 2016 to March 2017 were obtained from the data 
administrator. ${ }^{1}$ The first step was to pair the data in the database with the original school and new school for each student, as this information is not contained in the original set. Students who switched school once in this period, $N=4533$, were analysed.

To conduct further analyses, the database had to be localised geographically by assigning geographic coordinates to the student's place of residence and school location for each event. Therefore, the above dataset was merged with two other datasets.

2) ArcCR 500, the digital vector database of geographic data for Czechia, specifically the point layer of municipalities which are the lowest hierarchical administrative unit in Czechia;

3) vector point layer of upper secondary schools provided by the State Administration of Land Surveying and Cadastre.

These three databases were merged using the unique numeric municipal code used in all the databases. Subsequent analyses were conducted using the geographic information system (GIS) and various analytical tools. This way the spatial characteristics were assigned to 4,492 events, or school changes, (in 41 cases, i.e. $0.9 \%$, we could not assign all the spatial features owing to incomplete information in the original data).

The resulting dataset of events was then sorted into type according to the original and final educational track (see also Table 1). Transfer types with 25 and more individual events were entered into the further analysis $(4,406$ events). The omitted least frequent types of track switching represented only $2 \%$ of cases in the original dataset -11 of these (only $0.2 \%$ ) were students switching from a vocational track to the general academic tier $(\mathrm{L}>\mathrm{K}$ or $\mathrm{H}>\mathrm{K})$. Next, the events that were entered into the further analysis were broken down according to whether the event included both change of school and change of student's residence (residential move) or just change of school (non-residential move) and the resulting subset of 3,370 non-residential moves was then analysed (see Table 2).

It needs to be stressed that this was our first attempt to merge the administrative data on transfers between secondary schools with the geographical

1 Besides the data entered in our analysis, the register also provides information on student gender, semester and year of birth, citizenship, exact date of transfer, language of instruction and modern foreign languages taught in the original and new class/school. 
Table 2 Median distances from home to original and final school for different types of non-residential transfer $(\mathrm{N}=3370)$

\begin{tabular}{|c|c|c|c|c|}
\hline \multicolumn{2}{|c|}{ Transfer } & \multicolumn{2}{|c|}{$\begin{array}{l}\text { Median home-to-school distance } \\
(\mathbf{k m})\end{array}$} & \multirow[t]{2}{*}{$\begin{array}{l}\text { Median change } \\
\text { in distance } \\
(\mathbf{k m})\end{array}$} \\
\hline type & frequency (\%) & before transfer & after transfer & \\
\hline $\mathrm{M}>\mathrm{M}$ & 29.0 & 17.0 & 11.4 & -1.3 \\
\hline $\mathrm{H}>\mathrm{H}$ & 21.1 & 15.5 & 10.4 & -4.1 \\
\hline $\mathrm{K}>\mathrm{K}$ & 11.0 & 9.5 & 7.9 & -0.2 \\
\hline $\mathrm{M}>\mathrm{H}$ & 9.8 & 14.3 & 10.1 & -0.3 \\
\hline $\mathrm{K}>\mathrm{M}$ & 5.3 & 3.8 & 10.8 & 1.4 \\
\hline $\mathrm{L}>\mathrm{L}$ & 4.2 & 16.3 & 11.6 & -3.9 \\
\hline $\mathrm{M}>\mathrm{L}$ & 3.8 & 15.3 & 8.4 & -1.8 \\
\hline $\mathrm{H}>\mathrm{E}$ & 3.5 & 9.4 & 12.1 & 1.6 \\
\hline $\mathrm{M}>\mathrm{K}$ & 3.1 & 15.3 & 7.1 & -6.2 \\
\hline $\mathrm{H}>\mathrm{M}$ & 2.7 & 14.8 & 11.5 & -0.2 \\
\hline $\mathrm{L}>\mathrm{M}$ & 2.1 & 17.1 & 13.2 & -1.6 \\
\hline $\mathrm{L}>\mathrm{H}$ & 2.0 & 16.3 & 9.1 & -5.5 \\
\hline $\mathrm{E}>\mathrm{E}$ & 1.5 & 18.2 & 19.2 & -0.8 \\
\hline $\mathrm{E}>\mathrm{H}$ & 0.7 & 21.3 & 9.0 & -7.0 \\
\hline
\end{tabular}

Note: For type codes see Table 1. Source: Authors, based on Czech school register data

data. The above mentioned databases are used separately by educational science researchers and spatial information is regularly used in geoinformatics and geography. But it is rarer to find the data being discussed in relation to the new research dimensions by the parties concerned (Fjellman, Hansen, \& Beach, 2019).

Inductive research aimed at phenomenon and pattern discovery seems to be appropriate for working with new unique combination of datasets. We used exploratory data analysis (Jebb, Parrigon \& Woo, 2017), mainly data visualisation to spot patterns and outliers, and examine possible clusters and relationships. The descriptive data were obtained in our study and we focused on mean differences. Inferential techniques were not suitable for interpreting our results. As the study is based on population data, using 
inferential techniques could have resulted in us missing some meaningful patterns and trends (Gibbs, Shafer, \& Miles, 2015). Our preliminary findings need further study using more elaborated statistical techniques.

\section{Results}

In our data only $25 \%$ of transfers between schools could be linked to internal residential migration of the student (e.g. family moving from one municipality to another). We can expect that the decision to change programme (i.e. pursuing a different qualification), study track (possibly but not necessarily leading to a different qualification level), or school plays an important role in most transfers. In this section, we will refer to the school attended by the student before transfer as the "original school" and the new school as the "final school".

\section{Location of original school of choice}

The vast majority of students (98\% in the academic tier and on VET tracks) attended an original school within $100 \mathrm{~km}$ from their permanent residence (Figure 1). However, length of home-to-school distance differs between tiers. For vocational students, the median original home-to-school distance was $14.3 \mathrm{~km}$ (first and third quartiles: $6.0 \mathrm{~km}$ and $24.8 \mathrm{~km}$; average $18.0 \mathrm{~km}$ ). For academic tier students, the original median home-to-school distance was only $6.8 \mathrm{~km}$ (first and third quartiles: $1.9 \mathrm{~km}$ and $15.1 \mathrm{~km}$; average $11.5 \mathrm{~km})$. The remaining $2 \%$ will be analysed as outliers.

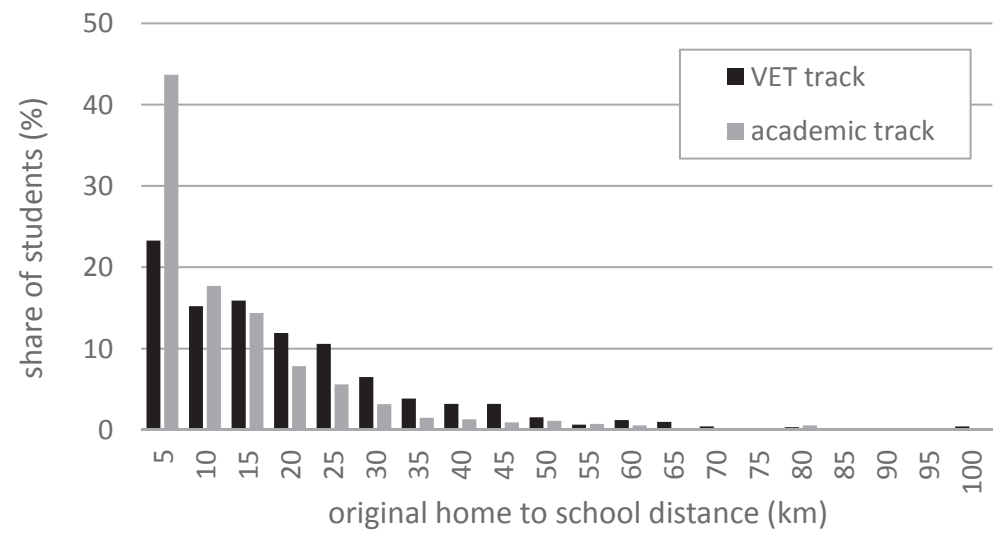

Figure 1 Comparison of distance from home to original school between academic tier students and VET (H track) students. Source: Authors, based on Czech school register data 


\section{Outliers}

We wanted to check the extreme values of home-school distances generated by our calculation to make sure they were not the result of a data processing error. The cut-off point was arbitrarily set at $100 \mathrm{~km}$; this corresponds to the 98th percentile. The remaining mobile students that originally attended a school more than $100 \mathrm{~km}$ away from their place of residence are analysed as outliers.

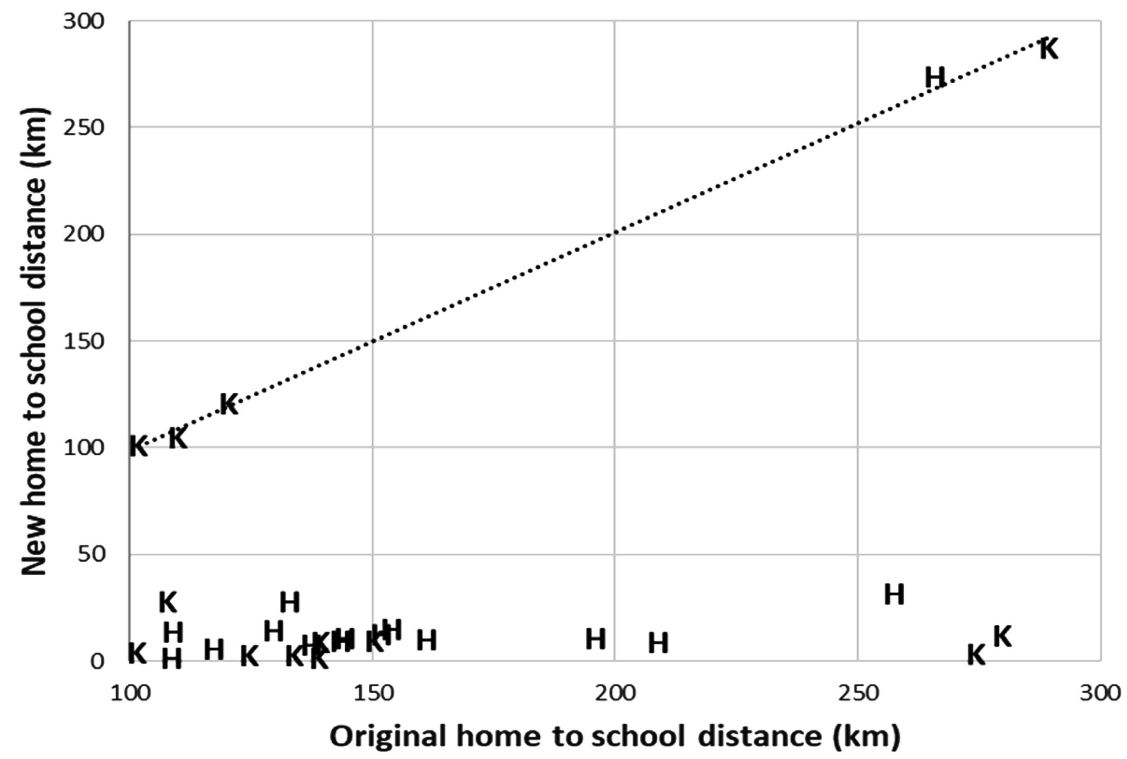

Figure 2 Outlier students originally in academic tier $K(N=13)$ and originally in vocational tier $\mathrm{H}(\mathrm{N}=16)$. Source: Authors

Figure 2 shows the relationship between distance to original and new school for the outliers: 13 students who originally attended the academic tier (10 of them transferred within the academic tier and 3 moved to the professional tier) and 16 transferred out of the vocational tier ( $\mathrm{H}$ track; all but one remained in the same tier and track). We can distinguish two categories of outlier events: the first group (upper part of the plot, for which a trend line has been added) consists of five students for whom the distance to the original and new school is far and almost the same. These events can be best explained by the hypothesis that the student's official (reported) and actual municipality of residence are not the same. We suppose that students in this group live in close vicinity to both the original school and the new school, but far away from their reported place of residence. Only one of the students originally attending the vocational $\mathrm{H}$ track seems to belong to this group. The second category of outliers consists of the remaining 9 students 
in the academic tier and 15 VET students for whom the home-to schooldistance following the transfer to the new school is significantly shorter. The place these students actually live most likely corresponds to that in the school records. They simply changed to a school close to their (new?) home. Either the change of school and the (probable) residential move were not simultaneous, or the students had originally attended a school far away from home, but changed school later. We conclude that there are plausible interpretations for the outliers that can be explained as properties of the input data, not a data processing error. This is illustrated by the information in the Appendix showing some students have a radical change in home-toschool distance (either an increase or a decrease).

\section{Typology of transfers}

All the non-residential mobility events (where there is no evidence of municipal emigration) were sorted according to the original and final track (using the track codes described in Table 1). There are 25 possible types of transfer within or between 5 tracks. The types of transfers with 25 and more events are listed in Table 2 and entered into the further analysis $(N=3370$ events, $98.1 \%$ of all non-residential transfers, see also Appendix). Given that we set out to study the transfers between schools as organisational units (transfers that include a spatial change in place of study), our data do not cover inter-track transfers within a single school that provides study programmes/qualifications belonging to different tracks.

Two thirds of cases are transfers between schools where the student stays within the same tier and track. The share of transfers within and out of the academic tier $(16.3 \%)$ is lower than the relative student population size in this tier. The pattern is reversed for student mobility in the professional tier $(45.7 \%)$ and the vocational tier (38\%). This result was expected. The general academic programmes are much more similar than the professional and vocational programmes, so changing programme is much less likely to be the reason for mobility within the academic tier. Transfers within the academic tier appear to relate more to the constellations in the school rather than the nature of the tier. Surprisingly, students are more likely to change schools for one that is closer to their home. One might expect that within the same tier (and particularly in the academic tier) the school of first choice would be the closest one.

When a student changes school and tier/track simultaneously, the average spatial characteristic of change varies from one type of transfer to 
another. As we demonstrated above, academic tier schools tend to be close to the student's place of residence, so changing from an academic to a professional tier tends to mean changing to a school further away, while the opposite is more likely when switching from the professional to the academic tier. Transferring from a less common E or L track to a more popular $\mathrm{H}$ track tends to shorten the home-school distance, while changing from the most typical VET H track to a less common E track results in a longer commute.

Figure 3 graphically summarises the most frequent school transfers involving track switching: a downward educational trajectory from a more prestigious tier (academic or technical professional) to vocational is more likely, the upward path is less travelled.

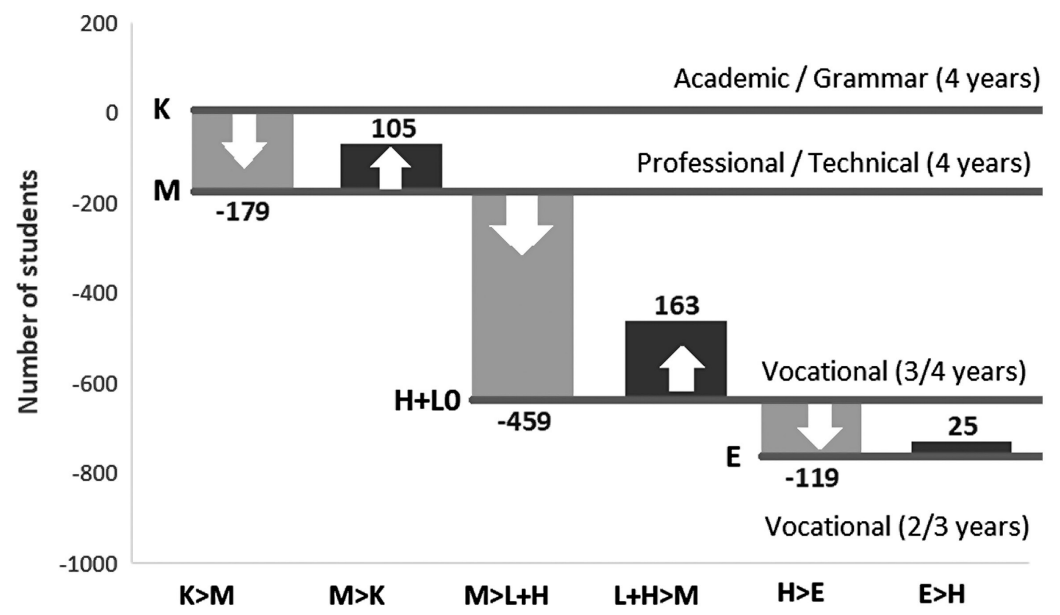

Figure 3 Cascade mechanism between tiers and tracks in Czech upper secondary education Source: Authors, based on Czech school register data

Change of field in vocational education

Table 3 shows the relative frequency of transfers within and between fields of study within a single track - H-programmes (three-year VET), typical blue collar trades and services. Data include both residential and non-residential transfers. Fields of study with the lowest share of students (e.g. mining) are omitted. Table 3 shows that almost half the mechanical engineering and manufacturing students (49\% of students changing school) continue their studies in the same field of VET after changing school.

Of these who switched field, 14\% changed to hotel and catering and nobody changed to health care. Health care programme students were most likely to change field of study when changing school (so the change in school 
Table 3 Patterns of change in field of study in 3-year VET $(\mathrm{H}$ track, $\mathrm{N}=828$ )

\begin{tabular}{|c|c|c|c|c|c|c|c|c|c|c|c|}
\hline \multirow[b]{2}{*}{$\begin{array}{l}\text { Mobile students' } \\
\text { original field of study }\end{array}$} & \multirow[b]{2}{*}{$\begin{array}{c}\text { Number } \\
\text { of mobile } \\
\text { students } \\
\text { (abs) }\end{array}$} & \multicolumn{10}{|c|}{$\begin{array}{c}\text { Share of students in new field } \\
\text { after changing school (\%) }\end{array}$} \\
\hline & & 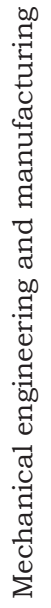 & 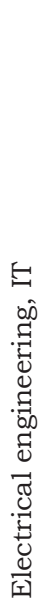 & 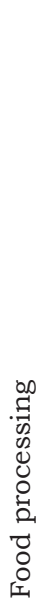 & 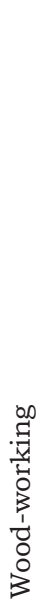 & 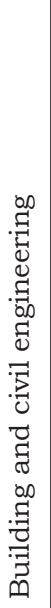 & 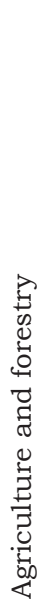 & 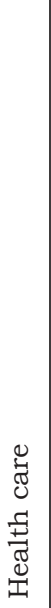 & 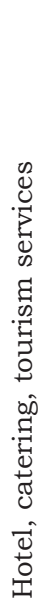 & 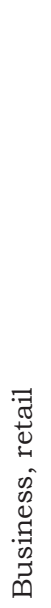 & 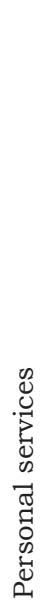 \\
\hline $\begin{array}{l}\text { Mechanical engineering and } \\
\text { manufacture }\end{array}$ & 227 & 49 & 5 & 3 & 2 & 10 & 11 & 0 & 14 & 7 & 1 \\
\hline Electrical engineering, IT & 78 & 15 & 37 & 3 & 3 & 5 & 18 & 0 & 17 & 3 & 0 \\
\hline Food processing & 47 & 2 & 2 & 45 & 4 & 2 & 4 & 2 & 21 & 13 & 4 \\
\hline Wood-working & 38 & 11 & 3 & 0 & 53 & 8 & 10 & 0 & 16 & 0 & 0 \\
\hline Building and civil engineering & 71 & 10 & 6 & 6 & 6 & 28 & 8 & 3 & 23 & 8 & 3 \\
\hline Agriculture and forestry & 70 & 23 & 3 & 0 & 1 & 1 & 43 & 1 & 20 & 3 & 4 \\
\hline Health care & 18 & 0 & 0 & 22 & 6 & 0 & 0 & 17 & 22 & 17 & 17 \\
\hline Hotel, catering, tourism services & 176 & 6 & 2 & 2 & 2 & 3 & 1 & 2 & 68 & 6 & 9 \\
\hline Business, retail & 39 & 0 & 8 & 8 & 0 & 0 & 13 & 0 & 26 & 36 & 10 \\
\hline Personal services & 64 & 0 & 0 & 5 & 2 & 2 & 5 & 3 & 14 & 6 & 64 \\
\hline
\end{tabular}

Note: The rows indicate the original field of study and the columns show the new field of study Source: Authors

was probably motivated by the desire to change field of study), while students pursuing a qualification in hotel, catering and tourism services or personal services usually continued in their original field of study after transferring to another school (so changing school was not related to the desire to change field of study).

A change in field always led to a shorter average school distance (see Table 4). The only exception is the most popular field of study - hotel, catering and tourist services. On the other hand, changing school without the change of field of study leads to varying results. In some fields of VET (e.g. 
Table 4 The average original home-to-school distance for students who changed and not changed the field when changing their school

\begin{tabular}{|l|c|c|c|c|}
\hline \multirow{2}{*}{ Original field of VET } & \multirow{2}{*}{$\begin{array}{c}\text { Number } \\
\text { of mobile } \\
\text { students }\end{array}$} & $\begin{array}{c}\text { Original } \\
\text { home-school } \\
\text { distance (km) }\end{array}$ & \multicolumn{2}{|c|}{$\begin{array}{c}\text { Change in home-school } \\
\text { distance (km) }\end{array}$} \\
\cline { 4 - 5 } & & same field & $\begin{array}{c}\text { change } \\
\text { of field }\end{array}$ \\
\hline Agriculture, forestry & 73 & 38.8 & -8.9 & -8.3 \\
\hline Personal service & 69 & 23.4 & -8.1 & -1.6 \\
\hline Wood-working & 39 & 23.2 & -9.7 & -4.9 \\
\hline Retail & 48 & 23.0 & -24.6 & -0.3 \\
\hline Electrical engineering & 86 & 18.9 & -1.3 & -6.1 \\
\hline Hotels, catering & 194 & 18.5 & 7.6 & 3.4 \\
\hline Food processing & 55 & 17.7 & 24.1 & -4.3 \\
\hline Mechanical engineering & 241 & 17.2 & -7.3 & -0.7 \\
\hline Health care & 22 & 16.9 & 114.9 & -3.1 \\
\hline Building & 76 & 16.4 & 11.2 & -6.6 \\
\hline
\end{tabular}

Source: Authors, based on Czech school register data

food processing, building), the average student must commute significantly longer distance after changing school. In other fields (retail), the new school tends to be closer to student's home. These differences have to be analysed in detail in order to explain them. Table 4 shows that for most fields of VET, the average home-to-school distance in our dataset was within the 16 to 23 $\mathrm{km}$ range. The only exception is agriculture and forestry.

\section{Discussion and Conclusions}

With respect to the empirical aim of the article, our study reports quantitative information on the typology and frequency of non-normative change of school in the Czech school system. Upper secondary students follow different tracks (usually in different schools) and there is a high share of students in the technical/professional and vocational training tiers. Students taking a VET tier choose one of several hundred programmes at the beginning. That is why in some cases a change of secondary school might be motivated out of an effort to correct a previous choice of school tier or track. We analysed the relationship between the presence or absence of a track (status) change, a programme change, and home-to-school distance of original and final school (spatial change) in the context of the Central European landscape and tracked school system which has strong professional and vocational components. 
Our result shows that in $67 \%$ of non-residential transfers, students remained on the same track after changing school. This result is important since some German studies (e.g. Müller et al., 2012, p. 66) have found, albeit in the context of lower secondary level, that "students rarely switch from one school to another on the same educational level", albeit the meaning of "rarely" is rather vague. Inter-school transfers within the same track might be the result of having chosen an unsuitable original programme (Bereményi \& Carrasco, 2018, Hlad’o \& Šlapalová, 2019). This explanation corresponds to our finding that within-tier transfers are relatively more frequent in the professional and vocational tiers. Another relevant explanation is that the quality of prestigious academic programs is more even across different schools (Kostelecký, Mikešová, \& Bernard, 2018), or putting it another way: the differences between vocational schools are perceived as more important.

Our data show that in some VET fields, namely health care, almost all the transferring students changed to other fields (so the purpose of the transfer was mainly to change field). While, in hotel, catering and tourism and in personal services most transferring students continued in their field of study. These results regarding the VET programmes still have to be compared with the data on professional tier programmes. There is also a group of transfers within the academic tier where the curriculum is relatively similar that cannot be explained by residential moves. Some of these events can be attributed to school-choice mechanism - students or families making a "strategic" change to attend a better school or a "reactive" change to avoid problems in the original school.

Regarding the spatial factors, the assumption that school specialisation and distance are substitutes (Müller et al., 2012; Prieto et al., 2018) is supported by our data on home-to-school distance for general academic and vocational schools. ${ }^{2}$ However, the finding that transfers within each tier are associated with shorter school distances can be explained by different mechanisms (Bertrand-Cloodt et al., 2010) and further detailed analysis is needed to better understand this result. For the most typical VET track (i.e. three-year $\mathrm{H}$ track), our results show that a change in field correlates with a decreased average home-to-school distance. This suggest that logistical

2 In our data and analyses, we do not differentiate between (a) students commuting daily to school and (b) boarding students, i.e. students living in school accommodation on weekdays (secondary students usually have to leave school accommodation at the weekends). In principle it should be possible to do this using the register of students who board. However, we cannot access or merge this data because of the method of student identification used. A new anonymous student identifier (identification number) would improve data access and expand the range of analytical possibilities. 
issues (commuting problems) could be an important factor in this subset of revised school choices. This is in line with the observation that school proximity to place of residence is very important across different social groups in Czechia and other countries (Meyer \& Kučerová, 2018; Müller et al., 2012; Prieto et al., 2018; Simonová, 2017). On the other hand, changing school without changing field of study had different effects. For some fields (e.g. food processing, building), the average student had to commute a significantly longer distance after the change. In others (e.g. retail), the new school tended to be closer to the student's home. These differences require further analysis before they can be explained.

Inter-school transfers associated with a residential move represent only a small proportion of all transfers. This corresponds to the fact that residential mobility is significantly lower in Central and Eastern European countries than in Nordic countries or the United States (Caldera Sánchez \& Andrews, 2011).

The methodological aim of the article was to test the analytical potential of merging previously unused administrative micro data contained in the Czech National Student Register with spatial data, at least in Czechia. However, this requires inter-disciplinary collaboration between education and spatial science researchers, such as those working in geography and geoinformatics, since the data analysis in particular steps is methodologically heterogeneous.

Education sciences are enriched by inter-disciplinary dialogue and the inclusion of spatial dimensions in the study of phenomena and processes occurring in the school system. Despite the spatial turn in social science in recent decades (Warf \& Arias, 2009), there has yet to be any routine application in education research of the theoretical conceptualisation of space, place and thinking in the vertical hierarchy of various spatial scales characteristic of geography or of methodological tools (such as geographical information systems). Collaboration with geographers could enable exploration of spatiality as a possible explanatory factor of some as yet unexplained processes in school systems. Geographers would be able to gain access to databases (in this case a subset of data from the Czech National Student Register) that require knowledge of the education system both for the initial sorting and the subsequent analysis, eliminating the risk of geographers misinterpreting it. 
A key limitation of our study is the lack of information on the socio-economic background and school achievement of mobile students - an important characteristic that is not available in any of the Czech administrative datasets, unlike in many other countries. Other studies have demonstrated that various socio-cultural groups of students are characterised by different patterns of inter-school mobility (e.g. Welsh, 2017). Often students from a disadvantaged background or who are members of ethnic minorities have higher mobility as a result of academic failure, lower educational aspirations or hardship. On the other hand, the focus on the downward trajectories of specific student groups in hierarchical systems with education tracks (van Praag et al., 2012) could lead to other types of inter-school mobility being neglected. The methodology for analysing the administrative data has considerable potential but the current system of data collection and management in the Czech school system lags behind advanced countries.

Another limitation of our results is the fact that we used a specific population - students that changed school once in the time interval investigated. The findings shed light on mobile students but some findings (such as the home-school distance patterns) cannot be generalised to the whole student population. We believe, however, that the methodology we have developed could be applied to other data from school registers and used to study spatial and occupational aspects of school choice in post-compulsory education. This approach is more suitable for studying choices in professional, vocational or higher education where we expect longer home-to school distances (compared to compulsory and general education) and hence the smaller relative error in our estimation of home location.

Yet another problem with our approach is that the distances used are the shortest or direct distances, not actual road distance or travel time. This problem could be addressed through the use of more advanced software tools, at least for a smaller subset of events.

This study was based on a quantitative approach that reveals interesting student pathways, but tells us little about why students changed school (or field). A qualitative retrospective study by Hlad’o \& Šlapalová (2019) provides some useful additional insights into the causes of mobility in Czech upper secondary education. The authors of this paper are now involved in a prospective qualitative longitudinal study with similar goals. 


\section{Acknowledgements}

This work was supported by a grant from the Czech Science Foundation (P402/12/G130 funded the work done by Dominik Dvořák; and GA18-19056S funded the work done by Jan Vyhnálek), The Internal Grant Agency of the J. E. Purkyně University in Ústí nad Labem (grant UJEPSGS-2018-53-004-2 funded the work done by Petr Meyer, Silvie R. Kučerová and Ondřej Šmid) and by the Grant Agency of the Charles University (grant number SVV UK 260425 funded the work done by Petr Meyer).

We express our thanks to staff at the Ministry of Education, Youth and Sport of the Czech Republic, Department of School Statistics, Analysis and Information Strategy for providing the administrative data.

\section{References}

Albrecht, R., Neumann, M., Jansen, M., Becker, M., Maaz, K., \& Baumert, J. (2018). Schulformwechsel im zweigliedrigen Schulsystem. Determinanten für das Nichtbestehen des Probejahres am Gymnasium in Berlin. Zeitschrift für Erziehungswissenschaft, 21(4), 839-865.

Backes, S., \& Hadjar, A. (2017). Educational trajectories through secondary education in Luxembourg: How does permeability affect educational inequalities? Revue Suisse des Sciences de l'Education, 39(3), 437-460.

Bereményi, B. Á., \& Carrasco, S. (2018). Caught in the triangle of mobility: Social, residential and pupil mobility. British Journal of Sociology of Education, 39(1), 32-46. Bertrand-Cloodt, D., Cörvers, F., Heijke, H., \& Van Thor, J. (2010). The impact of distance deterrence on the choice of field of study in vocational education in the Netherlands. Investigaciones de Economia de la Educacion, 5, 605-624.

Blank, C., Shavit, Y., \& Yaish, M. (2015). Tracking and attainment in Israeli secondary education. In D. Chernichovsky, \& A. Weiss (Eds.), State of the nation report 2015. Society, economy and policy in Israel. Jerusalem: Taub Center for Social Policy Studies in Israel. online: http://taubcenter.org.il/sin ger-series-state-nation-report-2015

Blossfeld, P. (2018). Social background and between-track mobility in the general education system in West Germany and in east Germany after German unification. Zeitschrift für Soziologie, 47(4), 255-269.

Caldera Sánchez, A., \& Andrews, D. (2011). Residential mobility and public policy in OECD countries. OECD Journal: Economic Studies.

Chubb, J. E., \& Moe, T. M. (1990). Politics, markets and America's schools. Washington DC: The Brookings Institution.

Danhier, J., \& Martin, E. (2014). Comparing compositional effects in two education systems: The case of the Belgian communities. British Journal of Educational Studies, 62(2), 171-189. 
Decree 211/2010 Coll., on system of qualifications in basic, upper secondary and post-secondary education.

Dobson, J. (2008). Pupil mobility, choice and the secondary school market: assumptions and realities, Educational Review, 60(3), 299-314.

Dvořák, D., Vyhnálek, J., \& Starý, K. (2016). Tranzice a transfer ve vzdělávací dráze: Longitudinální studie rizikového žáka. Studia paedagogica, 21(3), 9-39.

Dvořák, D., \& Vyhnálek, J. (2019). Meziškolní mobilita žáků středních odborných škol v České republice. Pedagogika, 69(2), 131-146.

Eurofound (2014). Mapping youth transitions in Europe. Luxembourg: Publications Office of the European Union.

Fjellman, A. M., Hansen, K. Y., \& Beach, D. (2019). School choice and implications for equity: The new political geography of the Swedish upper secondary school market. Educational Review, 71(4), 518-539.

Gasper, J., DeLuca, S., \& Estacion, A. (2012). Switching schools: Revisiting the relationship between school mobility and high school dropout. American Educational Research Journal, 49(3), 487-519.

Gibbons, S., \& Telhaj, S. (2011). Pupil mobility and school disruption. Journal of Public Economics, 95(9-10), 1156-1167.

Gibbs, B. G., Shafer, K., \& Miles, A. (2015). Inferential statistics and the use of administrative data in US educational research. International Journal of Research \& Method in Education, 4O(2), 214-220.

Holloway, S. L., \& Pimlott-Wilson, H. (2012). Neoliberalism, policy localisation and idealised subjects: A case study on educational restructuring in England. Transactions of the Institute of British Geographers, 37(4), 639-654.

Hlad’o, P., \& Šlapalová, K. (2019). „Už to dál nešlo“ - meziškolní mobilita ve středním odborném vzdělávání zpětným pohledem žáků. Pedagogika, 69(2), 147-164.

Jacob, M., \& Tieben, N. (2009). Social selectivity of track mobility in secondary schools. A comparison of intra-secondary transitions in Germany and the Netherlands. European Societies, 11(5), 747-773.

Jebb, A. T., Parrigon, S., \& Woo, S. E. (2017). Exploratory data analysis as a foundation of inductive research. Human Resource Management Review, 27(2), 265-276. Katrňák, T. (2004). Odsouzeni k manuální práci. Vzdělanostní reprodukce $v$ dělnické rodinè. Praha: Slon.

Koinzer, T., Nikolai, R., \& Waldow, F. (Eds.). (2017). Private schools and school choice in compulsory education. Global change and national challenge. Wiesbaden: Springer. Kostelecký, T., Mikešová, R., \& Bernard. J. (2018). Střední školy v regionech Česka: ovlivňuje periferní poloha nabídku škol, poptávku po nich a úspěšnost jejich studentů? In J. Bernard (Ed.), Nic se tady neděje... Životní podminky na periferním venkově (pp. 92-123). Prague: Slon.

Kvalsund, R. (2000). The transition from primary to secondary level in smaller and larger rural schools in Norway: comparing differences in context and social meaning. International Journal of Educational Research, 33(4), 401-423.

Landri, P., \& Neumann, E. (2014). Mobile sociologies of education. European Educational Research Journal, 13(1), 1-8.

Latina, J. (2017). Should I stay or should I switch? An analysis of transitions 
between modes of vocational education and training, Journal of Vocational Education \& Training, 69(2), 173-195.

Mehana, M., \& Reynolds, A. J. (2004). School mobility and achievement: a metaanalysis. Children and Youth Services Review, 26(1), 93-119.

Meyer, P., \& Kučerová, S. R. (2018). Do pupils attend the nearest elementary school to their homes? Factors in school choice in the urban environment of Liberec, Czechia. Acta Universitatis Carolinae Geographica, 53(1), 70-82.

Müller, S., Haase, K., \& Seidel, F. (2012). Exposing unobserved spatial similarity: Evidence from German school choice data. Geographical Analysis, 44(1), 65-86.

Prieto, L. M., Aguero-Valverde, J., Zarrate-Cardenas, G., \& Van Maarseveen, M. (2018). Parental preferences in the choice for a specialty school. Journal of School Choice, 13(2), 198-227.

Reeves, A., Friedman, S., Rahal, C., \& Flemmen, M. (2017). The decline and persistence of the old boy: Private schools and elite recruitment 1897 to 2016. American Sociological Review, 82(6), 1139-1166.

Rumberger, R. W. (2003). The causes and consequences of student mobility. Journal of Negro Education, 72(1), 6-21.

Simonová, J. (2017). Charakteristiky dobré základní školy z pohledu rodičů. Pedagogická orientace, 27(1), 136-159.

Straková, J. (2015). Strong vocational education - a safe way to the labour market? A case study of the Czech Republic. Educational Research, 57(2), 168-181.

Strand, S., \& Demie, F. (2006). Pupil mobility, attainment and progress in primary school. British Educational Research Journal, 32(4), 551-568.

Van Praag, L., Boone, S., Van Houtte, M., \& Stevens, P. (2012). Dropping down the cascade system: comparing the educational trajectories and perceptions towards tracking between and within ethnic minority and majority students in Belgium. Abstract of International Sociological Association Mid-term conference. Presented at the Transitions (Role/Status Exits and Entries), International Sociological Association (ISA).

Veselý, A. (2006). Kdo a proč končí v učňovských oborech? In P. Matějů, \& J. Straková et al., Nerouné šance na vzdělání. Vzdělanostní nerovnosti $v$ České republice (pp. 247-281). Praha: Academia.

Vojtěch, J., \& Chamoutová, D. (2018). Vývoj vzdělanostní a oborové struktury žáků a studentů ve střednim a vyššim odborném vzděláváni $v$ ČR a v krajích ČR a postavení mladých lidi na trhu práce ve srovnáni se stavem v Evropské unii-2017/18. Praha: Národní ústav pro vzdělávání.

Vyhnálek, J. (2016). Meziškolní mobilita: přehledová studie výzkumných témat. Orbis Scholae, 10(1), 63-96.

Vyhnálek, J., \& Dvořák, D. (2019). Přestupy žáků na druhém stupni základní školy: srovnání dvou případů, Studia paedagogica, 24(3), 7-45.

Warf, B., \& Arias, S., (Eds.) (2009). The spatial turn. Interdisciplinary perspectives. London a New York: Routledge.

Walterová, E. (Ed.). (2011). Dva světy základní školy? Úskali přechodu z 1. na 2. stupeñ. Prague: Karolinum.

Welsh, R. O. (2017). School hopscotch: A comprehensive review of K-12 student mobility in the United States. Review of Educational Research, 87(3), 475-511. 


\section{Appendix}

We examined the outlier cases of changing school where the extreme value of home-to-school distance was greater than $250 \mathrm{~km}$. All these cases involved switching from a school in the most eastern part of Czechia (i.e. eastern Moravia) to one in western Czechia (Western or North-Western Bohemia); the reasons for this are probably mainly geometrical - much of Czechia is spread out along an east-west axis with little land to the north and south, so it is probable this affects the distances involved in student mobility. All the outliers share another feature: there was no change in field of study and only in one case did a student change track (moving from the 3-year $\mathrm{H}$ track to the less demanding and often shorter $\mathrm{E}$ track programme). We can speculate that as no-one change field of study or track, the change of school was related to a non-reported residential move. In all four cases, the student's desired field of study was a commonly available one. If there had been other reasons (apart from change of residence) for changing school, the student would have been able to find another school providing the same programme much closer to home.

\begin{tabular}{|l|l|l|c|l|}
\hline $\begin{array}{c}\text { Student's } \\
\text { place } \\
\text { of residence }\end{array}$ & $\begin{array}{c}\text { Name of original } \\
\text { school and } \\
\text { destination school }\end{array}$ & $\begin{array}{c}\text { Location } \\
\text { of original } \\
\text { school/ } \\
\text { destination }\end{array}$ & $\begin{array}{c}\text { Distance } \\
\text { original/ final } \\
\text { (km) }\end{array}$ & $\begin{array}{c}\text { Original } \\
\text { and new } \\
\text { programme }\end{array}$ \\
\hline \multirow{2}{*}{ Horní Suchá } & $\begin{array}{l}\text { Střední odborné } \\
\text { učiliště }\end{array}$ & $\begin{array}{l}\text { Petrovice } \\
\text { u Karviné }\end{array}$ & 11.3 & cook \\
\cline { 2 - 5 } & $\begin{array}{l}\text { Integrovaná střední } \\
\text { škola }\end{array}$ & Cheb & 440.0 & cook \\
\hline \multirow{2}{*}{ Horní Bečva } & Hotelová škola & $\begin{array}{l}\text { Frenštát p. } \\
\text { Radhoštěm }\end{array}$ & 14.8 & confectioner \\
\cline { 2 - 6 } & $\begin{array}{l}\text { Střední škola } \\
\text { živnostenská }\end{array}$ & Planá & 405.5 & confectioner \\
\hline \multirow{2}{*}{ Zlín } & $\begin{array}{l}\text { Střední } \\
\text { zdravotnická škola }\end{array}$ & Zlinn & 2.4 & $\begin{array}{l}\text { nursing } \\
\text { assistant }\end{array}$ \\
\cline { 2 - 6 } & $\begin{array}{l}\text { Střední } \\
\text { zdravotnická škola }\end{array}$ & Karlovy Vary & 360.0 & $\begin{array}{l}\text { nursing } \\
\text { assistant }\end{array}$ \\
\hline \multirow{2}{*}{ Lovosice } & $\begin{array}{l}\text { Střední odborná } \\
\text { škola technická } \\
\text { a zahradnická }\end{array}$ & Lovosice & 1.2 & gardener \\
\cline { 2 - 6 } & Odborné učiliště & Kelč & 292.1 & $\begin{array}{l}\text { gardening } \\
\text { assistant }\end{array}$ \\
\hline
\end{tabular}

Distance $=$ distance from residence to original and final school $(\mathrm{km})$ 


\section{Authors:}

Dominik Dvořák

Charles University

Faculty of Education

Institute for Research and Development of Education

Myslíkova 7

11000 Praha 1

Czechia

dominik.dvorak@pedf.cuni.cz

Petr Meyer

Charles University

Faculty of Science

Department of Social Geography and Regional Development

Albertov 6

12800 Praha 2

Czechia

petr.meyer@ujep.cz

and

Jan Evengelista Purkyně University in Ústí nad Labem

Faculty of Science

Department of Geography

Pasteurova 15

40096 Ústí nad Labem

Czechia

Silvie R. Kučerová

Jan Evengelista Purkyně University in Ústí nad Labem

Faculty of Science

Department of Geography

Pasteurova 15

40096 Ústí nad Labem

Czechia

silvie.kucerova@ujep.cz

Jan Vyhnálek

Charles University

Faculty of Education

Institute for Research and Development of Education

Myslíkova 7

11000 Praha 1

Czechia

vyhnalekj@gmail.com

Ondřej Šmíd

Jan Evengelista Purkyně University in Ústí nad Labem

Faculty of Science

Department of Geography

Pasteurova 15

40096 Ústí nad Labem

Czechia

ondra.smith@seznam.cz 